\title{
Environmental Awareness in Terms of Public Health: Corporate Responsibilities
}

\section{Toplum Sağlığı Açısından Çevre Bilinci: Kurumsal Sorumluluklar}

\author{
Șifa ELÇiL'1
}

\begin{abstract}
The main cause of environmental problems is the increasing world population and people's consumption of the environment to earn more. As a result, the ecological balance is disturbed and environmental problems gain a global dimension. While some disciplines continue their research by focusing on environmental problems, an increasing emphasis is placed on the interaction between human and environment in the social field; it is observed that the sensitivity on this issue has increased in businesses. Environmental activities have increased rapidly with the support of various national organizations. These indicators draw the social responsibility areas of organizations. Minimizing environmental hazards has become the most important factor that improves the reputation and image of institutions in the public opinion, as well as providing corporations a competitive advantage. The aim of the study is to address environmental problems that threaten public health directly and in various ways; To reveal the importance of taking and implementing effective measures at the institutional level on environmental pollution. In conclusion, this study emphasizes that policies that provide solutions to environmental problems, which are a global problem today should be re-designed; international institutions should take a more active role, and cooperation is of great importance. .
\end{abstract}

Keywords: Public Health, Environmental Problems, Environmental Awareness, Environmental Pollution, Corporate Responsibility.

\section{Öz}

Çevre sorunlarının temel nedeni, artan dünya nüfusu ve insanların daha fazla kazanmak için yaşadıkları çevreyi tüketmeleridir. Bunun sonucunda ekolojik denge bozulmakta, çevre sorunları küresel bir boyut kazanmaktadır. Bazı disiplinler çevre sorunlarına yoğunlaşarak araştırmalarını sürdürürken, toplumsal alanda insan ve çevre arasındaki etkileşim üzerine giderek artan bir vurgu yapılmakta; işletmelerde bu konuyla ilgili duyarılıı̆ın arttığı gözlenmektedir. Çevresel faaliyetler, çeşitli ulusal kuruluşların destekleriyle hızla artmıştır. Bu tür göstergeler genel anlamda kuruluşların sosyal sorumluluk alanlarını çizmektedir. Bu nedenle çevresel tehlikelerin en aza indirilmesi, kurumlara rekabet avantajı sağlamanın yanı sıra kamuoyunda kurumların itibarını ve imajını geliştiren en önemli faktör haline gelmiştir. Çalışmanın amacı, halk sağlığını doğrudan ve çeşitli şekillerde tehdit eden çevre sorunlarının ele alınması; çevre kirliliği konusunda kurumsal düzeyde etkin önlem almanın ve uygulamanın önemini ortaya koymaktır. Çalışma sonucunda, günümüzde küresel bir sorun haline gelen çevre sorunlarına çözümler içeren politikaların yeniden tasarlanması; uluslararası kurumların daha aktif rol alması gerektiği ve iş birliğinin önemi vurgulanmaktadır.

Anahtar Kelimeler: Toplum Sağlığı, Çevre Sorunları, Çevre Bilinci, Çevre Kirliliği, Kurumsal Sorumluluklar.

Araștırma Makalesi (Research Article)

Gönderim Tarihi (Received): 27.02 .2021

Kabul Tarihi (Accepted): 30.05 .2021
Atıf (cite as): Elçil, Ș. (2021). Environmental Awareness In Terms Of Public Health: Corporate Responsibilities. Akdeniz Üniversitesi Iletișim Fakültesi Dergisi, 35, s. 359-369, DOI: 10.31123/akil.887695 


\section{Introduction}

The social life that people need in order to survive includes factors that both make life easier and also difficult for individuals. The increasing population of the world has also led to an increase in individual needs. Industrial Revolution was a milestone and the world has faced significant improvements within this process. Rapid population increases and technological developments have resulted in an increase in production and usage of more sources. Humans have been hell on nature and destroyed it, which was seen as an unlimited source, in order to use it for their increasing consumption and production demands. Development efforts in economical, social, technological and other areas have resulted in the omission of environmental values most of the time. A lot of countries transformed into developed countries thanks to the development efforts, especially those started after the World War II, but this also resulted in environmental problems threatening the humanity. Environmental problems, which have been ignored for the sake of development in the beginning, have transformed into global issues rather than local problems. Since the 1970s, the quest for a balance between development and nature has gained momentum. Hence, obtaining the balance between humans and the environment, which contains all the factors affecting humans and other living creatures, has become the main topic of the conversation. In the Burtland report published in 1987, the significance of a process meeting today's demands without sacrificing procurement of future generations' needs was emphasized. Today, a development concept considering the balance between development and natural resources, giving priority to the respect to the future generations is being called attention to (Ağca, 2020).

The rapid consumption of limited resources together with technological developments led to pollution of the environment and destruction of natural resources. As another factor, rapid urbanization and the increase in the population from developing regions to developed regions have also increased environmental problems. The issue of environmental protection and sustainable environment has started to gain importance in the world, especially after the 80s. Natural resources that have been lost over time have led people to take different measures. Environmental awareness as an individual and social responsibility is that people respect both themselves and nature. Awareness of how to make effective use of technology to protect the environment, how to solve problems and how to minimize potential future problems while benefiting from technological developments has begun to emerge in the world. As stated in the UNESCO program and the Gothenburg's report, sustainable development can only be achieved through a sustainable environment (Council of the European Union, 2006). The essence of economic development is based on human development, and the effective protection of natural resources is of primary importance for public health.

\section{Social Development and Public Health}

Investments in public health, as an element of social development, provide awareness and behaviour change about healthy living in individuals and societies. The studies on social welfare and health make a positive impression in society and increase trust in institutions. Activities related to the protection of natural resources and the protection of the environment are important for public health (Jeffery, 2006, pp. 604-608).

Starting from the education of individuals, sharing this understanding at the level of social consciousness has become a necessity. If the culture of a society considers the environment as 
an integral part of life, the strategies and practices to be developed in that society will be directed towards effective protection of the environment. The concept of sustainability stands out in the protection of public health, and it was defined in 1987 by the World Commission on Environment and Development as "meeting the needs of the present without compromising the ability of future generations to meet their own needs" (Jeffery, 2006, p. 33). In this context, besides the basic human rights, how the development is used by the members of the society has importance (Jacob \& Abel, 2002, p. 9). Sustainable development is related to the use of resources in the most efficient way, by protecting the limited resources in the world and respecting the environment. In light of the shared views, in general, the most important elements in sustainable development are ecology, nature and natural resources, economy and culture shared in society. Institutions were added later as a sub-element (De Kruijf \& Van Vuuren, 1998, pp. 4-14). It is stated that there are four main objectives in social development. These include a healthy and developing economy, a broad and balanced distribution of gains, a political system that guarantees human rights and freedoms, and an economic policy that considers effective leadership and environmental protection.

The environment is an environment where all living things live together. Natural resources, which are also among the factors of economic production, are considered as a component of the environment. Therefore, environment is a complex system consisted of physical, chemical, biologic, cultural and socio-economic sources and values (Noble, 2016, pp. 14-16). From this aspect, it can be stated that environment and humans are within very variable and complex activities. Environment is all the factors affecting the lives of living creatures, and consists of all living and non-living factors. Environment is the sum of the physical, chemical, biological, and social factors which might directly or indirectly affect the human activities and living creatures at a definite point in time. Accordingly, the living components of the environment are humans, flora, fauna, and microorganisms. On the other hand, non-living components are climate, air, water, and the structure of the Earth. Living and non-living creatures form the environment as a whole, and these components are in a continuous relationship with each other. Besides examining the environment under the categories of living and non-living environment, it can also be considered as physical and social environments according to its characteristics. The physical environment is the ambience where the living creatures live in, whose existence and characteristics are perceived physically by living creatures. While the environment which has occurred without any intervention of humans is called natural environment, that environment which has been changed in parallel with the aims of humans is called artificial environment. Artificial environment reflects the knowledge, technology and social values of the society of the period during which it was created. On the other hand, social environment is an ambience which consists of all the economic, social and political relations of humans. From this aspect, physical and social environments are complimentary to each other. Therefore, environment is not only a large area in which creatures live, but also a huge ecosystem inhabiting millions of living creatures. Furthermore, environment is all the historical and cultural values from which humans procure their biologic and physical needs in order to continue their lives (Yücel, 2020). Humans have been in direct interaction with environment during each stage of their lives, have used the sources contained in environment, benefited from them and have continued an environmentally friendly life for years, but have never cared about it.

Mankind, having seen the nature as an unlimited source for centuries, have used and polluted it, and caused the occurrence of environmental problems. Both increasing population and the existence of natural resources which are being depleted have obliged humans to find new solutions. Within this 
context, it is a must to transfer natural sources to the future generations without consuming them out. This understanding attaches importance on humans, and proposes to protect and consume the environmental resources to meet the needs of the society with care by considering the needs of the future generations. Against the fact that natural resources are limited and can be consumed out, protection of environment and its sustainability are unavoidable. Protection of environment has a priority of social health as a social development factor.

\section{Environmental Awareness as a Public Health Factor}

As a result of the processes experienced after the industrial revolution in Europe, today, health policies have been established in many countries around the world. There are funds and supports allocated to public health at national and international levels. In general terms, environmental policy is a country's measures and principles related to the solution of environmental problems. Environmental policy is about setting goals for securing the global environment, maintaining environmental values, eliminating damages arising from the production/consumption activities of people and institutions, and deciding how to share the costs associated with the measures to be taken (Mutlu, 2006, p. 70). In this context, measures should be taken before environmental damages arise, and the measures to be taken should be reflected in the decision-making processes.

The environment, as a medium where living and non-living beings coexist and interact, is a set of universal values. Plant, animal communities, non-living beings, and the civilizations and products created by man throughout history are the common existence of all humanity (Bozyiğit \& Karaaslan, 1998). The environment covers many areas. Besides, environment, economy and social factors are elements indispensable of sustainable development as interrelated concepts. In terms of institutions, the environment is the medium which includes air, water, soil, natural resources, plant and animal systems in which an institution operates. The environmental impact of institutions is any harmful or beneficial change that occurs in the environment in relation to the product and service activities of the institutions (Keleş \& Hamamcı, 2002). Institutions should not provide products and services that are harmful to human health and pollute the environment during their production activities.

On 31 May 2019, TMMOB Chamber of Environmental Engineers made a press declaration before 5 June, the Worlds Environment Day, and shared the World Environment Day Turkey Report with the public. According to this report, about 30,000 people died due to the reasons stemming from air pollution every year in Turkey. This health problem stems from fossil fuel usage, and it has been increasing in our country. The air in Turkey is about 33.4\% more polluted than EU. The ratio of fossil fuels causing air pollution in Turkey's energy production is $88 \%$. Briefly, the theme determined by the United Nations is very valuable for Turkey in order to take the attention on the most significant environmental problem encountered in Turkey (Türk Mühendis ve Mimar Odaları Birliği, 2019).

In 2017, about 34.4 billion TL was spent for the protection of the environment. While $49 \%$ of this amount was spent for waste management, 35\% was spent for wastewater management. On the other hand, only $2 \%$ was spent for avoiding and decreasing outdoor air pollution and for climate. Air pollution is one of the most significant problems of Turkey. There is a need to allocate a bigger budget for the solution of this problem. In Turkey, positive developments occur in the environment management area, and the number of regular collection areas and wastewater treatment plants has increased, infrastructure has improved and forestation works have been performed. On the other 
hand, environmental pollution increases, existing forest tissue is being destroyed, there were idle wastewater treatment and fresh water treatment plants, and rivers, air and soil in Turkey are being contaminated. For example, while there were 44 million hectares of pasture areas, corresponding to $56 \%$ of the land of the country in 1920, this figure decreased to 14.6 million hectares corresponding to $19 \%$ of the land of the country in 2014 (Türk Mühendis ve Mimar Odaları Birliği, 2019). Therefore, it is both a social and corporate responsibility to talk about these issues and make contributions to the solution and create awareness in the society.

Efforts to protect public health raise life goals (Lu, et al., 2017, p. 136). Due to the global impact of environmental problems, for the protection of public health, many international organizations are involved in this process. Setting certain standards all over the world will yield beneficial results for all communities. In this context, the protection of the environment as a factor that directly affects the public health has become of primary importance. Establishing a strong understanding of the internalization of environmental protection policies in all societies and institutions operating in the community and the integration of these policies with other fields will contribute to the process.

\section{Protection of the Environment as Corporate Responsibility}

Together with the industrial revolution, the development of production policies by institutions created new employment areas. However, as institutions act only for profit, an understanding that regards all means as permissible has prevailed. In addition to consumer rights and employee rights, environmental damage was also been ignored. Over time, employees and society became conscious, and institutions became unable to meet the expectations of the changing masses. After productions solely for profit, various reactions to institutions against noise, air, water and solid waste and similar environmental pollution developed (Akıncı \& Vural, 2011, pp. 4-5). The understanding of social responsibility and the environment began to develop with the evolution of values in the 1930s towards social morality. In those times, non-governmental organizations, women's movements and social movements related to environmentalism promoted the social responsibility of the institutions (Bartol \& Martin, 1994). British industrialist Sheldon, one of the most important representatives of the concept of social responsibility that also covers the understanding of the environment, felt the need to change in the management philosophies after World War I, and became more interested in social problems. Saying that "The first responsibility of the management is to serve to the society", he pointed out the concept of social responsibility (Peltekoğlu, 2005, p. 171). Thus, all rapidly developing social responsibility and environmental activities around the world began to be implemented around the 2000s in Turkey. This understanding is an important contributor to corporate reputation today.

Concerns about the social and environmental effects of corporate activities and the anxiety for the environment are multidimensional (Yazdi \& Khanalizadeh, 2017, p. 1182). In general, personal and corporate organizations focus on the following issues: increase in the solid waste, water and air pollution, decreasing resources, chemical articles and destruction of nature (Engin, 2004, pp. 11-25). The corporations are expected to obtain a harmony between the effects of their acts and activities on the society and the norms, values and benefits of the society. In parallel with the increasing interest and sensitivity of the consumers and the public on these issues in recent years, some of the consumers question the sensitivity and good faith of the corporations about these issues (Torlak, 2009, p. 110). Consumers desire security and safety in human and environment related issues. Competition conditions have changed in parallel with the change of expectations 
from the corporations. It is obvious that corporations have to make some arrangements in their production activities under the frame of the new competition conditions. It is especially required to make sustainable changes to ensure the efficient use of environmental resources and create production systems with a prudent and preventive understanding. For this purpose, a structure consisting of efficient and clean technologies should be established and made sustainable. At this point, environmental effects should also be taken into consideration. Corporations might adopt different applications. On the other hand, these applications are successful only if they are ethically consistent for the corporation, increase the wealth and benefits of the society, and are in compliance with corporate strategies (Story \& Neves, 2015, pp. 111-124). In other words, the concept of corporate responsibility is questioned universally, and a diversity of applications stemming from different dimensions of the concept draws attention (Capelle Blancard \& Petit, 2017, pp. 919-943). While the corporations are acting towards their own aims, they become more aware of the specific needs and desires of the society in which they operate. The basic reason for this is the evaluation of the environmental activities of corporations by the society and all the stakeholders of the corporation and the meanings given to the corporation as a result of this evaluation (Dahlsrud, 2018, pp. 1-13).

As part of the society and the world in which they live, institutions are accountable to the entire society and humanity. Institutions have obligations such as, at the most basic level, fulfilling the legal responsibilities, paying taxes, treating employees fairly; at the second level, protecting the environment by foreseeing the damages to the environment by the institution, preventing pollution and the use of products produced in the institution for harmful purposes; and at the third level, fulfilling its responsibilities for a healthy society and tackling all social problems (Okay, 1998, p. 70). Institutions have responsibilities towards society as well as economic and legal responsibilities (McGee, 1998, p. 378). If the main responsibilities of the institutions that express their responsibility towards society are considered under four headings, these are voluntary responsibilities, ethical responsibilities, legal responsibilities and economic responsibilities (Carroll, 1979, p. 499).

Davis and Blomstrom expressed the responsibilities of the institutions with the 3-circle model, and explained the corporate social responsibility of the institutions with three circles that are intertwined and grow from inside to outside. Accordingly, the first inner circle refers to the responsibilities arising from the basic economic functions, the second circle refers to the responsibilities arising from economic activities, and the third circle refers to the responsibilities regarding the solution of social problems. In other words, solution-oriented practices for education, health, environmental pollution, and similar issues are emphasized by Davis and Blomstrom (Davis \& Bloomstrom, 1975, pp. 5-23). Hunt and Grunig expressed corporate responsibility in the same direction as Davis and Blomstrom (Peltekoğlu, 2005, pp. 168-169):

- Basic tasks of the organization,

- Taking into account the external effects of the activities of the organization,

- Dealing with general social issues not related to the organization.

Therefore, the responsibility of institutions for social benefit, independent of institutional and personal interests, is of great importance. Institutions are obliged to maintain a strategy and policy in line with economic and legal conditions, business ethics, and expectations of all stakeholders inside and outside the organization. 
Today, issues such as business ethics and corporate governance have come to the fore, and the corporate social responsibility approach has also taken its place on the agenda. Corporate social initiatives are large-scale activities undertaken to support social goals and fulfil corporate social responsibility obligations (Kotler \& Lee, 2006, p. 3). On the other hand, under the encouragement and leadership of international organizations (UN, OECD, ILO, EU), institutions are required to be more careful and sensitive in complying with the standards developed for human rights, employee rights, and environmental protection (Aktan, 2007, p. 11). Reputable journals of the business world express social responsibility and environmental protection as a performance criterion in corporate performance. Besides, many funds in the world evaluate an institution's social responsibility and environmental performance before investing in it.

\subsection{Major Sources of Environmental Pollution in the World}

Individuals have begun to become conscious and react to the pollution of the environment. In recent years, many studies have been carried out on environmental protection. The technological and managerial power of man has reached the effect that will change the balance of nature (Özüpek, 2008, p. 270). The interaction between the human and environment is emphasized in these studies. Environmental problems are mainly due to the fact people desire to gain and consume more together with the increase in the population of the world, and they see their self-interests above society's common interests and values. Industrial activities, chemicals and waste polluted the air and water. The realization that the ozone layer is pierced, the return of the Chernobyl disaster in Alaska, the Exxon-Valdez accident and today's warming climate disasters have increased the environmental awareness of societies. Environmental movements increased with the support of non-governmental organizations in the new Europe.

According to the report of the right to clean air platform, it shows that $91 \%$ of the world population breathes polluted air according to the limits of the World Health Organization. Furthermore, findings from the studies performed in England last year revealed that polluted air reaches even to foetus. Due to all these developments, air quality management has become a more significant issue both for citizens and the decision makers in all over the world. When we have a look at the reflections of these issues in Turkey, the research performed by Konda Research Corporation revealed that the people considered air pollution as the most important environmental problem in Turkey in 2018. The participants of the research also stated that air pollution is a problem which affects their life most in the place where they live (Temiz Hava Hakkı Platformu, 2019). Therefore, environmental pollution is both a national and global treat. It causes the death of about 12.6 million people every year in the world. Destruction of environment by humans results in the questioning of the situation of nature and the dimensions of the environmental pollution.

In the report published by World Health Organization in 2017 , it was stated that unhealthy and polluted air is the cause of death for 1.7 million children under age five, i.e. $25 \%$ of the deaths among these group of children in all over the world (Gömeç, 2017). These unhealthy environments occur due to air and water pollution, passive smoking and lack of hygiene, and result in diarrhoea, malaria and pneumonitis. In this report, it was also stated that undeveloped organs and immunity systems of the children under five are affected from water and air pollution very much. The report entitled "Inheriting a Sustainable World: Child Health and Environment Atlas" emphasizes that environmental pollution might affect even foetus, and little children might become passive smokers 
and suffer from air pollution in indoor and outdoor environments in their future life. As a result of this, the risk of pneumonitis for children increases, and they suffer from chronic respiratory diseases like asthma during all their life. It is also stated that especially air pollution would increase the risk of cardiovascular diseases, cancer and paralysis for the children in the future. The report emphasizes that while $9.5 \%$ of the babies under 60 months suffer from developmental disorders, $10.9 \%$ of them are overweight. It is also stated that children are subject to chemicals from food and the products surrounding them. About 300 million children in all over the world live in a place where the air pollution rates are six times more than the limits determined by World Health Organization, and about 600 thousand children lose their lives due to air pollution every year (Gömeç, 2017). All governments and institutions need to work together to eliminate risks to health.

Although the efficiency on unit area has increased in agriculture in all over the world, increase on population and consumer demands oblige the protection of agricultural areas. While total agriculture areas were 4.92 billion hectares in 2000 in all over the world, this figure dropped to 4.83 billion hectares in 2017. Agricultural areas decreased in Turkey, too. According to 2018 TUIK data, total agricultural area dropped to 37.8 million hectare, and processed agricultural area dropped to 23.2 million hectares. Decrease in agriculture area stems from allocation of agricultural lands for other purposes, becoming non-agricultural land since some small sized corporations cannot obtain sufficient income, and from deformation of soil due to wrong agricultural operations and wrong land usage (Ziraat Mühendisleri Odası, 2020).

Today, when primary environmental problems are considered, it is seen that air, water, soil and noise pollution reach dangerous limits. Air is vital for people. As a result of the rapid increase in population, rapid urbanization and industrialization, the air in the atmosphere is polluted. Again, economic activities concentrated in certain regions and the population concentrated in these regions have led to the need for more energy resources. This increases the air pollution. The release of waste gases into the atmosphere as a result of the activities of the institutions and the lack of adequate measures on this issue is another problem. The lack of adequate technology in developing and underdeveloped countries, and the fact that developed countries realize polluting industrial production in developing countries are the most important reasons why this situation cannot be prevented. Industrialization and population also lead to water, soil and noise pollution.

According to the surveys, consumers state that they will boycott products that harm the environment. Some consumers state they will not buy the products of these institutions. Therefore, environmentally sensitive institutions allocate resources for environmental protection activities and adopt this understanding as a strategic goal (Şatır \& Öztekin, 2005, p. 145). National and international standards have been introduced to prevent environmental pollution. But it is a common responsibility to ensure that these standards are applied throughout the world. The increase in the environmental movements, the studies carried out, and the support of the public to the environmentally sensitive institutions affect the activities of the institutions (Odenhal, 2008, p. 27). The negative impact of industrial activities on the environment has increased social awareness. The importance given to the environment by the institutions is emphasized as a priority issue in their mission and vision, executive speeches, annual performance reports, corporate presentations and social responsibility activities. This ensures that institutions receive public support and contributes to their credibility and reputation. 


\section{Conclusion}

Nowadays, concerns about the social and environmental effects of corporate activities have increased. A balance must be managed between institutional activities and community norms. Consumers, who are the most significant stakeholders of the corporations, and other stakeholders desire security and safety in humanistic and environmental issues. Institutions should regulate their production activities. For this purpose, a structure consisting of efficient and clean technologies should be created and made sustainable. Corporations can be successful when they adopt corporate strategies that emphasize social good. Social responsibility activities are applied in many different subjects. While organizations act in line with their own strategic goals, they become more aware of the special needs and demands of the society in which they operate. The main reason for this is that institutions are monitored by all their stakeholders. In this study, environmental problems which threaten public health directly and from multi-dimensional aspects are remarked, and the significance of taking efficient measures at corporate level against environmental pollution and application of them is underlined. Policies that include solutions to environmental problems at the global level need to be redesigned. At this point, the more effective role of international organizations and cooperation will contribute to the process. As a result of this study, it was emphasized that the policies include solutions to the environmental problems which have become global issues should be redesigned, and international institutions should play a more efficient role and work in cooperation.

Humanity has provided continuous scientific and technological development in order to provide better living conditions, and these developments and industrialization have caused important environmental problems that will affect the ecological system. Today, environmental problems have become the most important problem of humanity as a global problem that transcends borders and includes inter-country dependence. Lost natural resources have led societies to take different measures. Environmental awareness is people's respect for themselves and nature. Awareness about utilizing technology effectively for the protection of the environment and solving problems has begun to emerge. The essence of economic development is based on human development, and the effective protection of natural resources is importance. At this point, it is important for individuals to develop social behaviours related to environmental protection and to maintain similar behaviours as a common culture throughout life. In order to achieve this understanding, it is a necessity to develop and maintain environmental awareness individually, institutionally and socially as well as an effective environmental policy. Educational institutions, mass communication institutions and nongovernmental organizations also play an important role in raising environmental awareness. Keeping environmental protection, environmental problems and environmental awareness on the agenda is extremely important. Sustainable development can only be achieved with a sustainable environment. In conclusion, taking and applying efficient measures against the roots of the environmental problems threatening public health in all over the world appears as new areas of study. 


\section{References}

Akıncı, Z., \& Vural, G. (2011). Corporate Social Responsibility and Ethics. Gümüşhane Üniversity Faculty of Communication Electronic Journal, 3(1), 4-5. https://dergipark.org.tr/tr/pub/e-gifder/issue/7474/98417.

Aktan, C. (2007). Kurumsal Sosyal Sorum/uluk. İstanbul: İgiad.

Bartol, K. \& Martin, D. (1994). Management 2. Baskı, London: Mc Garw-Hill.

Bozyiğit, R. \& Karaaslan, T. (1998). Çevre Bilgisi. Ankara: Nobel.

Capelle, B. G., \& Petit, A. (2017). The Weighting of CSR Dimensions: One Size Does Not Fit All. Business and Society Sage, 56(6), 919-943. https://doi.org/10.1177/0007650315620118.

Carroll, A. (1979). A Three-Dimensional Conceptual Model of Corporate Performance. The Academy Of Management Review, 4(4), 499. https://doi.org/10.5465/amr.1979.4498296.Dahlsrud, A. (2018). How Corporate Social Responsibility is Defined: An Analysis of 37 Definitions. Corporate Social Responsibility and Environmental Management, 15(1), 1-13. https://doi/pdfdirect/10.1002/csr.132.

Davis, K. \& Blomsstrom, R. (1975). Environment and Responsibility, Business and Society. New York: Mc Graw Hill Book Co.

De Kruijf, H., \& Van Vuuren, D. (1998). Following Sustainable Development in Relation to the North-South Dialogue: Ecosystem Health and Sustainability Indicators. Ecotoxicology And Environmental Safety, (40), 4-14. https://doi. org/10.1006/eesa.1998.1635.

Engin, Ö. (2004). Yeşil Pazarlama. Mevzuat Dergisi, 7(78), 11-25.

Jacob, T. \& Abel, R. (2002). Sustainable Development and Health: An Indian Perspective. Lancet 360, 24(638), 9. https://doi.org/10.1016/S0140-6736(02)09778-7.

Jeffery, J. (2006). Governance For A Sustainable Future. Public Health, 120(7), 604-608. https://doi.org/10.1016/j. puhe.2006.04.004.

Keleş, R. \& Hamamcı, C. (2002). Çevrebilim. Ankara: İmge.

Kotler, P. \& Lee, N. (2006). Kurumsal Sosyal Sorumluluk. İstanbul: Mediacat.

Lu, Z., Chen, H., Hao, Y., Wang, J., Song, X. \& Mok, T. M. (2017). The Dynamic Relationship Between Environmental Pollution, Economic Development and Public Health: Evidence From China. Journal of Cleaner Production, 166(1), 136. https://doi.org/10.1016/j.jclepro.2017.08.010.

Mcgee, J. (1998). Commentary on Corporate Strategies and Environmental Regulations: An Organizing Framework. Strategic Management Journal, 19(4), 378. https://doi.org/10.1002/(SICI)1097-0266(199804)19:4<377::AIDSMJ988>3.0.CO;2-S.

Mutlu, A. (2006). Küresel Kamusal Mallar Bağlamında Sağlık Hizmetleri ve Çevre Kirlenmesi: Üretim, Finansman ve Yönetim Sorunları. 21.Türkiye Maliye Sempozyumu: Kamu Maliyesinde Güncel Gelişmeler. Maliye Dergisi, 150(1), 70. https://ms.hmb.gov.tr/uploads/2019/12/img-150.pdf\#page=60.

Noble, C. (2016). Green Social Work - The Next Frontier for Action. Social Alternatives.35(4), 14-16. https://search. informit.org/doi/10.3316/ielapa.872133296471245.

Odenhal, S. (2008). Buyer Be Good. Alternatives Journal, 34(4), 27. https://doi:10.1177/0022343399036006004.

Okay, A. (1998). Halkla Ilişkiler Aracı Olarak Sponsorluk. İstanbul: Epsilon. 
Özüpek, N. (2008). Sosyal Sorumluluk Halkla Ilişkiler. Konya: Tablet.

Peltekoğlu, F. (2005). Halkla Ilişkiler Nedir. İstanbul: Beta.

Story, J., \& Neves, P. (2015). When Corporate Social Responsibility Increases Performance: Exploring The Role of Intrinsic And Extrinsic CSR Attribution. Business Ethics. A European Review, 24(2), 111-124. https://doi.org/10.1111/ beer.12084.

Şatır, Ç., \& Öztekin, Z. (2005). Social Responsibility and Ethics. Journal Of Istanbul University Faculty Of Communication, (22), 145.

Torlak, Ö. (2009). Modern Dünyada Yeşil Pazarlama Ne İfade Ediyor. Çerçeve Dergisi, (Ocak), 108-112.

Yazdi, S. \& Khanalizadeh, B. (2017). Air Pollution, Economic Growth And Healthcare Expenditure. Economic Research, 30(1), 1181-1190. https://doi.org/10.1080/1331677X.2017.1314823

Yücel, E. (2020). Canlılar ve Çevre. Türkiye: Anadolu Üniversitesi.

Ziraat Mühendisleri Odası. (2020). X. Teknik Kongresi Bildiriler Kitabı-1. Ankara.

\section{İnternet Kaynakları}

Ağca, B., (2002). Dünya Sürdürülebilir Kalkınma Zirvesi, Johannesburg. https://www.Mfa.Gov.Tr/Dunya-SurdurulebilirKalkinma-Zirvesi_Johannesburg_-26-Agustos---4-Eylul-2002_.Tr.Mfa adresinden 20 Nisan 2020 tarihinde erişilmiştir.

Gömeç, G. (2017). Yeşilist. https://www.Yesilist.Com/Dunya-Saglik-Orgutu-Cevre-Kirliligi-Yilda-1-7-Milyon-CocugunOlumune-Yol-Aciyor/ adresinden 21 Nisan 2020 tarihinde erişilmiştir.

Temiz Hava Hakkı Platformu, (2019). Hava Kirliliği ve Sağlık Etkileri, İstanbul. https://www.Ttb.Org.Tr/Userfiles/Files/ Hava-Kirlilig\%CC\%86i-Ve-Sag\%CC\%861\%C4\%B1k-Etkileri-Kara-Rapor-2019.Pdf adresinden 5 Ekim 2020 tarihinde erişilmiştir.

Türk Mühendis ve Mimar Odaları Birliği. (2019). Dünya Çevre Günü, Ankara. https://www.Tmmob.Org.Tr/lcerik/Cmo2019-Dunya-Cevre-Gunu adresinden 21 Eylül 2020 tarihinde erişilmiştir. 